\title{
NATAL É TEMPO DE CORRER COM A EXECUÇÃO ORÇAMENTÁRIA
}

Coluna publicada em 11.12.2012: <http://www.conjur.com.br/2012-dez-11/ contas-vista-natal-tempo-correr-execucao-orcamentaria $>$

O Natal está chegando, com ele o final de ano, as festas e, em breve, o novo ano. Época oportuna (ou inoportuna?) para algumas considerações sobre a execução orçamentária, tema talvez um tanto quanto inadequado para esse período festivo...

Retomo hoje, nesta coluna, assuntos que, de certa forma, já foram objeto de referência anteriormente com a finalidade de chamar a atenção para algumas questões interessantes.

O sistema orçamentário brasileiro tem como ponto central a lei orçamentária, que cada ente da nossa Federação (União, estados, DF e municípios) deve elaborar, aprovar e executar anualmente.

Nossas leis orçamentárias têm vigência pelo período de um ano, que corresponde ao ano civil, por força da legislação nacional aplicável (Lei 4.320, de 1964, art. 34), produzindo seus efeitos, portanto, de $1^{\circ}$ de janeiro a 31 de dezembro de cada ano.

Nem sempre foi assim, nem todos os países seguem essas datas, mas a conveniência ou não de mantê-las é objeto de outra discussão, a ser feita oportunamente (algumas observaçôes acerca deste tema o leitor poderá ver na minha coluna de 20 de novembro de 2012 - No primeiro ano de mandato, não se cumprem promessas). Sendo assim, as despesas nelas previstas devem ser efetuadas nesse período, caso contrário terão de ser novamente inseridas no orçamento para que os valores possam ser gastos no próximo exercício.

Como já escrevi na coluna de 31 de agosto de 2012 (Não falta dinheiro à administração pública, falta gestão, nesta edição, p. 255-258), "Gastar dinheiro público não é fácil, e nem deve ser. Submetidas a uma série de procedimentos e controles, 
com a louvável finalidade de evitar desvios e mau uso dos recursos públicos, a despesa pública é um ato complexo. Previsão legal no orçamento, licitações, empenho, cronogramas, liquidações, enfim, há um longo percurso até o desembolso".

Da dotação consignada no orçamento, no início do ano, até o efetivo desembolso, há um longo caminho a percorrer, como se pode observar, e esse percurso exige organização, disciplina e muito trabalho, o que nem sempre se verifica na imensa administração pública brasileira. A complexidade em se concretizar o gasto público, aliada a um possível - talvez provável, ou certo... - comportamento de "deixar para a última hora", faz com que, todos os anos, invariavelmente, às vésperas do Natal, os administradores públicos se vejam às voltas com a necessidade de gastar os recursos previstos no orçamento, sob pena de, não o fazendo, correrem o risco de ficar sem eles no ano seguinte.

Abro um pequeno parênteses nesse ponto para esclarecer a "perda" de recursos que não foram gastos.

O Brasil adota o que é usualmente chamado de "orçamento incrementativo". E o que significa exatamente isso? A elaboração da lei orçamentária é uma tarefa complexa, em que são necessários estudos e debates - técnicos e políticos - envolvendo toda a sociedade, uma infinidade de pessoas e órgãos, para que, ao final, se possa chegar à lei orçamentária aprovada, na qual estão discriminadas as receitas, bem como as despesas, detalhadas por órgãos, programas, ações governamentais etc. Seria ideal que a cada ano todos esses detalhes fossem minuciosamente analisados e debatidos a fim de que cada orçamento pudesse representar com a maior fidelidade possível os anseios da população.

É o que se propõe com a adoção da técnica orçamentária do "orçamento base zero", já tentada algumas vezes, sem o esperado sucesso. As dificuldades de implementação dessa técnica levam à generalidade dos países em adotar a técnica do "orçamento incrementativo", por meio do qual os debates a cada novo orçamento partem do orçamento elaborado e executado, de modo que as alterações ocorrem pontual e gradualmente, com poucas possibilidades de grandes e repentinas transformações.

Dessa forma, há uma tendência à manutenção dos programas, ações governamentais e respectivas dotações, ano após ano. Como consequência, valores de dotações previstas em uma lei orçamentária e não utilizados terão grande possibilidade de serem "cortados" do orçamento seguinte, pois ele será elaborado com base no que foi previsto e executado no exercício anterior. E as dotações que forem utilizadas, ainda que mal utilizadas, mantidas.

Compreensível, embora não plenamente justificável, o comportamento dos gestores públicos, ao passar o final de ano correndo para gastar dinheiro público, 
quando deveriam estar mais preocupados em escolher o peru e acompanhamentos para as festas natalinas...

Fechados parênteses, volto ao tema central já chamando a atenção para um paradoxo: como se falar em correr para gastar o dinheiro previsto no orçamento? Significa que o dinheiro está sobrando, quando todos sabem que está faltando?

Pois é. Sobrando e faltando ao mesmo tempo, difícil de explicar, mas os gestores públicos não terão dificuldade em entender e confirmar. Estranho, mas real e verdadeiro.

O pior são as consequências nocivas que esse comportamento causa às finanças públicas.

$\mathrm{Na}$ ânsia de gastar, por vezes impera o "vale-tudo". Não importa se o gasto é útil, necessário, atende ou não ao interesse público, já que a prioridade passa a ser "limpar o caixa" a qualquer custo. Nessa hora, muito do escasso dinheiro público é desperdiçado com despesas de menor relevância, por vezes desconectadas do sistema de planejamento das ações governamentais, causando distorçôes nos rumos da administração.

Priorizam-se despesas de fácil execução, que dispensam procedimentos complexos, como licitaçôes, que inviabilizariam o gasto do dinheiro antes de findo o exercício.

Na falta de tempo para avaliar prioridades, promove-se uma "caça ao tesouro" em que ganham os mais rápidos, mais espertos e mais sortudos.

Certamente, ficam felizes os contemplados, destinatários dos recursos, bens ou serviços para os quais as dotações foram generosamente liberadas.

Quem perde sou eu, você, somos nós - afinal é o dinheiro público que vai para o ralo.

O assunto aparece com alguma frequência na mídia nessa época do ano, ainda que não se possa identificar à primeira vista. No O Estado de S.Paulo de 7 de dezembro de 2012 (Por acordo no orçamento, Dilma libera R \$ 3,4 bilhōes em emendas), anuncia-se que "para aprovar a proposta orçamentária de 2013 antes do recesso parlamentar, o governo se comprometeu a liberar $\mathrm{R} \$ 3,4$ bilhóes em emendas de parlamentares nos próximos dez dias. Pelo acordo fechado com a oposição, cada um dos cerca de 100 deputados e senadores do DEM, do PSDB e do PS vai ter empenhados R $\$ 5$ milhões de suas emendas ao Orçamento deste ano até o dia 20 de dezembro, data prevista para a votação no plenário do Congresso da proposta orçamentária para o ano que vem. Para os quase 500 parlamentares da base aliada, o Palácio do Planalto vai empenhar R \$ 6 milhões em emendas orçamentárias”. 
Mais um uso para este verdadeiro "peru de Natal" que são os recursos ainda não gastos no final de exercício: a barganha com os parlamentares, a que já me referi na coluna de 3 de julho de 2012 (Emendas ao orçamento e desequilíbrio de poderes, nesta edição, p. 219-222). A liberação de recursos das dotações contingenciadas desde o início do ano, cujo gasto deveria ser feito de forma planejada e transparente, transforma-se em "moeda" para a "compra de votos" necessária à aprovação da lei orçamentária.

Lei orçamentária que, por sua vez, contemplará dotações para despesas que os parlamentares exigiram nela inserir, sem o que não votariam a lei orçamentária. Contemplará também dotações de interesse do governo, para as quais a inserção no orçamento, por vezes, custou algumas liberações de recursos orçamentários que estavam "sobrando" no final do ano. Dotaçōes essas que, após inseridas, serão contingenciadas à espera do final do ano seguinte e, assim, segue o "ciclo orçamentário" (que, frise-se, não é o significado que a doutrina do Direito Financeiro dá à expressão...).

Certamente a estória se repetirá no ano seguinte, como já vem ocorrendo há anos (ou décadas, quiçá séculos...).

Mas um ano novo é sempre época de renovação das esperanças. Que a quebra desse "círculo vicioso orçamentário" entre na lista de desejos.

E um feliz 2013 a todos! 